\title{
Teaching International Law in Times of Change and Crisis
}

\author{
Sari Kouvo ${ }^{1}$ \\ Department of Law, University of Gothenburg, Sweden
}

\begin{abstract}
This article is a contribution to scholarship on the teaching of international law, in general, and in Nordic countries, in particular. The article draws on lessons from international law as situated and embedded in national and regional politics and systems of governance. That is, although international law is international, it is approached and implemented differently depending on situation and location. The article emphasizes that contemporary teaching of international law should engage with how situation and location matters for how international law is approached and it should also reflect contemporary global challenges. The article uses the ongoing conflict in Afghanistan as an example, as well as experiences from teaching international law with the help of a peacemaking role-play focused on the conflict in Afghanistan.
\end{abstract}

Keywords: International law, pedagogy, Afghanistan, peace, conflict, Nordic countries.

\section{Introduction}

\section{Three Lessons and an Aim}

In his opening statement to the UN General Assembly in 2014, the UN Secretary-General Ban Ki-Moon noted that 'the world's fasten your seat belt sign is illuminated'. Citing ongoing conflicts in places such as the Central African Republic, Ukraine, Mali, Iraq and Syria, the Secretary-General noted that it "...had been a 'terrible year' for the principles enshrined in the United Nations Charter" and that it "...may seem as if the world is falling apart." (UN doc GA/11560). He called for political leadership that sowed the seeds

\footnotetext{
${ }^{1}$ Address: Sari Kouvo, Department of Law, School of Business, Economics and Law, University of Gothenburg, Box 650, SE-405 30 Gothenburg, Sweden. E-mail: sari.kouvo@law.gu.se
} 
of positive change and that also enabled the seeds to grow. Since then, the accumulation of violent conflict and crisis has continued, ${ }^{2}$ as well as the rise to power of political leaders with divisive rather than unifying agendas. ${ }^{3}$

A few years ago, I returned more fully to academic life and to the teaching of international law, after having worked for 15 years in and on issues relating to Afghanistan and crisis management more broadly. ${ }^{4}$ Moving back into academia provided me with an opportunity to observe world developments, including the continued conflict in Afghanistan, with greater distance. It also provided me with an opportunity to reflect on what my European crisis management and Afghan experience have meant for how I think about international law and how I teach it.

When attempting to make the connection between my practical experience and international law, three observations stick out. ${ }^{5}$ First, international law is situated. The fundament for international law principles, customary and treaty law and jurisprudence is largely the same for Afghanistan and Sweden, where I now have my academic base. However, all international law obligations are not equally relevant or realistic when analyzed from the perspective of conflict-ridden Afghanistan and the largely stable and prosperous Sweden or Nordic countries more

\footnotetext{
${ }^{2}$ Quantitative data on violent conflict, conflict and terrorism-related deaths and military expenditure shows ebbs and flows over the past century, but with a clear increase over the past decade. For example, the quantitative data from the Uppsala Conflict Data Program shows a rise in armed conflict from the end of the Second World War to today, https://www.pcr.uu.se/research/ucdp/charts-graphs-and-maps/ (accessed 2020-09-15). The data from Our World in Data shows that although violent conflicts between states and especially major world powers have been less frequent in this century than previously, the last decade in particular has seen a rise in battle-related deaths and terrorism and conflict-related deaths, https://ourworldindata.org/war-and-peace (accessed 2020-0915). The Stockholm International Peace Research (SIPRI) quantitative arms and military expenditure shows a steady rise in military expenditure over the past decade, https:/www.sipri.org/media/press-release/2020/globalmilitary-expenditure-sees-largest-annual-increase-decade-says-sipri-reaching-1917-billion (accessed 2020-09-15).

${ }^{3}$ The past decade has seen a shift towards nationalism in several world powers, including permanent members of the UN Security Council, such as the United States, China, Russia and the UK. Several other major world powers are also experiencing increasing political polarization and/or a rise to power of nationalist or populist parties, including India, the Philippines, Thailand, Brazil, Italy, France and Germany. This political shift affects cooperation at the global level and accentuates geopolitical tensions. For interesting perspectives compare, for example, the International Crisis Group's conflict watch lists from January and May 2020,

https://www.crisisgroup.org/latest-updates/eu-watch-list (accessed 2020-09-15). See also, Freedom House's assessment of the decline in democracy and basic freedoms over the past decade, https://freedomhouse.org/report/freedom-world/2020/leaderless-struggle-democracy (accessed 2009-09-15).

${ }^{4}$ Over the last 15 years, I worked for five years for the EU's foreign service. First, for the EU Special Representative's Office in Afghanistan and later for the Crisis Management Planning Directorate of the European External Action Service. The remaining ten years, I worked for non-governmental organizations and policy think tanks, including Amnesty International, the International Centre for Transitional Justice and the Afghanistan Analysts Network.

${ }^{5}$ For an overview of scholarship relevant to the lessons, see section Theory and Method.
} 
broadly. More importantly, information about breaches and violations of international law do not have the same reach or impact in Afghanistan as they do in Nordic countries. Second, international law is truly inter-national and political. It is evoked when those around the table have an interest in it; it can also be ignored or broken. This does not make international law irrelevant, as those around the table often do have an interest in international law, but it does mean that legal advice is not automatically sought or acted upon. Third, diverse and often incoherent interests guide government approaches to international law and its implementation. That is, location and politics or geopolitics help explain government positions vis-àvis international law, but such explanations do not provide insights into tensions between different ministries or other national constituencies on specific international law issues. Neither do they shed light on how individuals working with international law can actually effect change. The lessons are not unique. Below, in the Theory and Method section, I will seek to situate them within scholarship on international law. However, the lessons have helped shift my own thinking and how I teach international law from viewing international law as a coherent system 'out there', to explaining it as embedded in and relevant to national, regional and international politics.

The focus of this special issue is the role of legal theory in legal education, as well as on whether or how legal education should tackle societal and global challenges. In the planning process for the special issue, it was not defined what was meant by societal or global challenges. The evident content could include global challenges, such as working towards the realization of Agenda 2030's 17 sustainable development goals (2015). ${ }^{6}$ Of course, national strategies will not suffice in solving most global challenges, be they pandemics, climate change, terrorism or other forms of violent extremism. They demand multilateral cooperation and commitment to the institutional platforms established and action plans drawn up to bring about solutions. With geopolitical tensions mounting and violent conflicts increasing, creativity, expertise and stamina are needed from the many diplomats, civil servants and lawyers negotiating solutions. Making use of the three lessons, I will, in this article, explore the teaching of international law. I will do this from two perspectives. First, I will take a bird's eye

\footnotetext{
${ }^{6}$ https://sustainabledevelopment.un.org/sdgs (accessed 2019-05-25)
} 
perspective on international law teaching in general and in Nordic countries in particular. Second, based on a role-play focused on peacemaking in Afghanistan that I use in my own teaching, I will reflect on ways to equip today's law students in becoming tomorrow's empathic and engaged problem-solvers.

\section{Theory and Method}

This article draws extensively on the author's own experiences as a practitioner and as an international law lecturer. Building and problematizing one's own experience is a well-established methodological approach in critical legal scholarship used by, for example, David Kennedy in his critique of human rights and humanitarian practice (Kennedy 2009) or Dianne Otto's reflection on peoples' tribunals (Otto 2017). In a less personal style, it is also used by several human rights scholars who bring their experience from working as UN special rapporteurs, members of human rights committees or other international positions into their academic deliberations. Some notable examples are Michael O'Flaherty, currently Director of the EU Agency for Fundamental Rights, or Fionnuala Ní Aoláin, currently UN Special Rapporteur on the promotion and protection of human rights and fundamental freedoms while countering terrorism (O’Flaherty 2007; Aoláin 2016).

The three lessons that international law is situated and political and government approaches to it are diverse draw on my experience, but the lessons are not unique. They also draw on contemporary international scholarship, in particular scholarship that emphasizes inter-disciplinary approaches, and studies international law at the intersection between law, politics and international institutions (see for example Dunoff and Pollack 2013; Koskenniemi 2009). Particularly relevant for the two first lessons are critical, feminist and postcolonial perspectives on international law that have repeatedly shown how history, location and power have contributed to both structural biases in international law and its institutions (see for example Anghie 2012 and Orford 2006). Similar lessons also emanate from comparative international law scholarship (Roberts 2017) and from the growing body of scholarship in the intersection between international law and politics (see for example Baaz 2019; Dunoff and Pollack 2013). This latter scholarship is of course also relevant for the third lesson, on governments' diverse approaches to international law. Although it remains more limited, 
there is also interesting scholarship emerging that focuses on the role of specific groups of experts, institutions and changes in international policy and law (for example Zidra and Gauci 2016).

This article also draws on the rapidly growing field of study on higher education pedagogy in general, and international law pedagogy in particular. ${ }^{7}$ A comprehensive overview of scholarship about international law teaching is Christine Schwöbel-Patel's (2018) entry on the subject in the Oxford Bibliographies in International Law. Scholarship on teaching international law can also be found within this body of scholarship that seeks to bring new perspectives and knowledge into teaching, including feminist and third world postcolonial perspectives (see, for example, Otto 2000; Saberi 2015; Sen 2020). It also draws on scholarship that seeks to innovate with method. The latter scholarship includes a focus on teaching methodologies and, not surprisingly, a growing body of scholarship on how to teach international law in the digital age (see for example Cattafi 2018; Beck 2010; Gazzini 2016).

\section{Structure}

After this introductory part, the second part focuses on international law teaching in general, and in Nordic countries in particular. The third part of this article focuses on Afghanistan. It provides a brief overview of the ongoing conflict in Afghanistan and the development of the conflict in relation to international law. It also includes the account and analysis of a role-play focused on a possible Afghan peace deal that I have used in various international law courses. The red thread through the two parts are the three lessons presented in the introduction, which are that international law is situated and political and government approaches to it are diverse.

\footnotetext{
${ }^{7}$ The topic of teaching international law is a recurring topic on the International Law Association's agenda, as well as on that of the European Society of International Law and the American Society of International Law (see the European Society of International Law (ESIL), http://esil-sedi.eu/, the International Law Association (ILA), http://www.ila-hq.org/ and its American Society of International Law (ASIL), https://www.asil.org/ and the website of its interest group for teaching international law, https://www.asil.org/community/teachinginternational-law, (accessed 2019-05-27). For a critique on how professional associations approach the topic of teaching international law, see Gamble 2007. It is beyond the scope of this article to give an overview of the developments in higher education pedagogy. However, comprehensive introductions to the subject include academic journals, such as Higher Education Pedagogy.
} 


\section{International Law and Legal Education}

\section{Teaching International La win Different Geographies}

This section provides an introduction to current scholarship on international law teaching. It discusses this scholarship in relation to the three lessons mentioned above. The past decades have seen a growing body of scholarship focused on international law teaching and higher education pedagogy in general. ${ }^{8}$ In her overview of scholarship on international law teaching, Schwöbel-Patel (2018) notes that a distinction can be made between pre- and post-1990s scholarship on international law teaching, where earlier scholarship focused on what is taught and later on how it is taught. However, scholarship focusing on how international law is taught also reflects on the often intimate connections between location, politics and law. ${ }^{9}$ For example, Schwöbel-Patel emphasizes that different national and regional experiences result in different approaches to teaching international law. She makes a distinction between countries with a civil law tradition, where the teaching of international law is influenced by law being viewed as science and countries with a common law tradition, where the emphasis is more on international legal practice. She also draws a distinction between international law teaching in Western and non-Western states, in particular states with a colonial legacy. She notes that in Western law schools the idea of international law's neutrality continuous to dominate, while non-Western law schools struggle with communicating the relevance of the subject and developing curricula with regionally relevant content.

An excellent empirical analysis for how location and politics or geopolitics matter for international legal academia including teaching is Anthea Roberts's Is International Law International? (2017). This knowledge and analysis does in turn contribute to making international lawyers - academics and practitioners alike - more reflective of their own and others' biases and blind spots. Through an empirical study of the work of leading international law scholars and the course books used in élite universities in China,

\footnotetext{
${ }^{8}$ The topic of how to teach international law was already debated in the early $20^{\text {th }}$ century (Whittuck 1917; International Law Teaching 1925; McNair 1943).

${ }^{9}$ The question of how location, politics - and history - matter for teaching international law is a topic often evoked in critical and third world perspectives on international law (Kennedy 1985; Gamble 2007; Zahralddin-Araven 2001; Israel 2017; Al Attar and Tava 2010; Cerone 2011; Saberi 2016).
} 
France, Russia, the United Kingdom and the United States - the five permanent members of the UN Security Council - Roberts shows how location shapes how international law expertise is framed and taught. Roberts suggests that what is needed is a comparative international law approach. A comparative approach could help challenge “...international lawyers' romantic understanding of themselves and their field as universal and cosmopolitan". She continues:

Introducing a comparative element helps to disrupt this assumption by showing that other communities of international lawyers - often in different states or geopolitical regional groupings - approach international law in different ways. This knowledge encourages international lawyers to be more reflective about the limits to their understanding of and approach to the "international", and how much the way they have been socialized, the networks they have developed, and the sources on which they rely have led to or reinforced these limitations (Roberts 2017, 14).

Lack of awareness about one's own possible confirmation biases and scholarly silos, and how these are passed on to new generations of lawyers through legal education is always worrying as it affects the quality of research, education and can also be detrimental for international lawyers' ability to, for example, effectively advise foreign or multilateral diplomacy.

The silo effect does occur within thematic areas of international law scholarship and across geographies. I will briefly exemplify this with, first, an example from feminist perspectives on international law and second, borrowing Roberts's examples of the Crimean conflict.

Feminist scholarship on international law has grown from its modest 1980s beginnings to a vibrant research field that today covers most aspects of international law. Feminist scholarship has then carved out an important space for itself within the discipline of international law, but this has not necessarily changed or deepened the disciplinary debate as feminist scholars continue to largely 'talk to themselves' (Charlesworth 2011).

Much feminist international legal scholarship presents itself as being in conversation with the mainstream of international law. We ask the mainstream to consider women's lives when applying or developing the law; we critique the assumptions of international legal principles; 
and we argue for an expanded referential universe. This conversation is, however, almost completely one-sided; a monologue rather than a dialogue (Charlesworth 2011, 17).

There is value in 'talking to ourselves', it enables fine-tuning theoretical, methodological and empirical expertise and depth within specific areas. However, it needs to be balanced with 'talking to others' to ensure crossfertilization of research and to make sure that a research field does not become irrelevant over time because it is not understood and its relevance has not been communicated. Shifting from monologue to a dialogue of course also involves listening by all who participate in the dialogue. So far, there have been few in-depth engagements with feminist international legal scholarship, although there is a growing number of token references to feminist scholarship, and most international law textbooks today include chapters (usually towards the end) focused on new, critical or feminist and postcolonial perspectives on international law.

Roberts exemplifies the silo effect with how international law scholars from different UN Security Council member states debated Crimea's annexation by or reunification with Russia (Roberts 2017, 231). The crisis in Ukraine started after the Ukrainian government opted for closer ties with Russia and the Eurasian economic region instead of signing an association agreement with the EU. This resulted in largely student-led demonstrations and violent clashes in Kiev, but also other parts of Ukraine. The demonstrations forced the government to resign and a new government was formed that vowed to end corruption and the power of the oligarchs over the Ukraine government and to establish closer ties with the EU. The developments displeased neighboring Russia that had long-standing ties with Ukraine in general and within Ukraine's autonomous Crimean peninsula in particular. A referendum was held in Crimea asking citizens whether they wanted Crimea to continue to be part of Ukraine or re-join Russia. The Crimean population chose the latter option. However, the legality of the referendum was questionable, as was the Crimean population's ability to actually choose freely given the massive mobilization of pro-Russia militias receiving support from Russia in Crimea.

The Crimean crisis resulted in political tensions between the US and EU on the one side, and Russia on the other side, nearing Cold War levels. While much of the dominant current in the European foreign policy debate 
seemed focused on the crisis as an expression of Russian expansionism and disregard for international law, some senior diplomats lamented to this author that the European diplomatic corps no longer learnt Russian and that exchange visits between parliaments, analysts, artists, and youth that had been fostered during the Cold War were no longer prioritized. An early Euromaidan activist aired similar sentiments as she told this author, that she 'joined the revolution' because she did not want Ukraine to be in the hands of corrupt officials or to close its door to the EU. However, she also noted that Ukrainians should not be forced to choose as they had important cultural ties to both Russia and Europe. The political crisis was splitting families, with the older generations feeling an allegiance towards Russia and the youth being more EU-minded.

The silo effect of the political debate was mirrored within the scholarly international law debate, notes Roberts. Russian scholars writing in Russian discussed the Crimean case as one of democracy and self-determination, and European scholars writing in English discussed it as an act of aggression and violation of Ukrainian sovereignty. There were a few efforts towards scholarly debate across the divide (Roberts 2017, 234). Most notably, a symposium was organized under the auspices of the Heidelberg Journal of International Law. ${ }^{10}$ The organizers of the symposium noted that:

The contemporary academic debates in Russia, Ukraine and other Eastern, Central and Western European states seem to be conducted in isolation and detached from each other. We perceive an urgent need to offer spaces for scholarly exchanges in which these academic universes meet and might refer and connect to each other. It is a truism but maybe worth repeating at this occasion that the function and purpose of international law as a global order demands a genuinely transnational academic and practical legal discourse whose participants accept that arguments are sound only if they are fit for universal application. ${ }^{11}$

Schwöbel-Patel and Roberts contribute to the understanding of my first two lessons, that international law is situated and political. They also shed light on how this matters for how international law is taught in different

\footnotetext{
${ }^{10}$ http://www.mpil.de/files/pdf4/Marxsen_Peters_Hartwig_Symposium_Intro.pdf (accessed 2020-09-27).

${ }^{11}$ http://www.mpil.de/files/pdf4/Marxsen_Peters Hartwig_Symposium Intro.pdf (accessed 2020-09-27).
} 
geographies. Roberts' example of the lack of communication between European and Russian international law scholars also indirectly sheds light on my third lesson, that government approaches to international law are eclectic. International law may be situated and political, but scholars, diplomats, civil servants, legal advisors, journalists and analysts are not trapped by geopolitics. As an academic, analyst or journalist, it is possible to reflect on and ask questions about one's own and others' biases and blind spots. As a diplomat, civil servant or legal adviser, it is possible to integrate the knowledge of biases into policies and actions.

\section{Teaching International Legal Subjects in the Nordic Countries}

In Schwöbel-Patel's overview, the Nordic countries - Denmark, Finland, Iceland, Norway and Sweden - would fall within the broad category of 'Western' states with civil law traditions. At a more aggregated level of historical and geopolitical analysis, Nordic countries do distinguish themselves from continental Europe. The intertwined histories and (to some extent) shared languages among Nordic countries have created opportunities for cooperation both within the region and internationally (Pettersson 2005; Hilson 2008). Nordic countries do, for example, have their own regional organization, the Nordic Council, established in 1952. During the 1950s, it facilitated the creation of the Nordic Passport Union and the Nordic labor market. However, the importance of Nordic cooperation has dwindled as some of the Nordic states (Finland, Denmark and Sweden) have joined the European Union and others have joined NATO (Norway). Historically, Nordic cooperation has extended to international politics and law and the Nordic countries certainly continue to be represented in the same diplomatic groups of 'like-minded' countries. ${ }^{12}$

However, does this cooperation still extend to a Nordic approach in international law? This was one of the questions that was asked at a conference on Nordic approaches to international law (2015) that resulted in the publication of a special issue of the Nordic Journal of International Law (2016). In the opening article for the special issue, Gregor Noll engages with what he perceives to be a Nordic identity of the past dating back to $19^{\text {th }}$ century neutrality politics and what he calls 'mid-20 $0^{\text {th }}$ century Nordic

\footnotetext{
${ }^{12}$ The author herself has worked with Nordic, Nordic+, EU and EU+ like-minded groups in Afghanistan and at the EU headquarters in Brussels.
} 
international legalism' (Noll 2016, 267). Based on the analysis of three contemporary case studies - focused on the use of force, international recognition, and international humanitarian law - he concludes that "a common Nordic approach to international law hardly exists today" (Noll 2016, 267). Two of the other articles in the special issue, Julie Gjørtz Howden's (2016) analysis of the Nordic 'community of interest' in the area of international waters law and Cecilia Bailliet's (2016) analysis of the Nordic approach to promoting women's rights in the area of international law show the continued potential of a Nordic approach. ${ }^{13}$ Both authors note, however, that Nordic cooperation in the fields that they examine could have gone further. The remaining articles that engage with a Nordic approach are largely inward-looking and focus on the role of international treaty law and jurisprudence from the European Court of Human Rights in judicial decision-making in Nordic countries (Wind 2016; Bjorgvinsson 2016).

The special issue, then, seems to suggest that the era of Nordic countries attempting to jointly put their mark on international politics and law has passed, but that concretely Nordic countries continue working closely together in various international forums. Whether the authors consider it good or bad or are indifferent towards Nordic cooperation and their results in the area of international politics and law seems to depend on whether they view Nordic cooperation as risking the creation of an exclusionary Nordic identity or as being about strategic partnerships for a good cause. On the one hand, Noll asks us to reject "our idiotic longing for the Nordic, the Greek, the identic, the authentic and the communal and instead turn it into openness - and openness that is concrete, historically situated and at work in the world" $(2016,280)$. On the other hand, Gjørtz Howden argues that a 'community of interest' approach constructed "on trust, solidarity and community" is particularly suited for the Nordic region $(2016,351)$. This author's experience - both from seeking to support the coordination of a European foreign policy on Afghanistan from within the Office of the EU Special Representative for Afghanistan and from advising the EU's crisis management structures in Brussels - is that a Nordic 'identity' and 'community of interest' can do both. Cooperation is generally smooth and

\footnotetext{
${ }^{13}$ An interesting research project is currently ongoing at Oslo University focused on Nordic branding. The project has also included a focus on international law, https://www.uio.no/english/research/strategic-researchareas/nordic/research/research-groups/nordic-branding/ (accessed 2020-09-23).
} 
efficient with Nordic colleagues, including a varying handful of other likeminded nations. However, whether it is useful depends on how Nordic cooperation affects approaches to other regions and also, of course, which interests are promoted in this cooperation. While it may be efficient - or familiar - to work in this community of interest, it goes without saying that the attitude 'we know each other and work well together' risks marginalizing regional approaches and interests that are deemed foreign. That is, whatever brings us together in a community of interest can also be used as a mechanism for exclusion. Curiosity and readiness to discuss and debate can be a result of diplomatic and professional experience, but the seeds for it can also be sowed during education.

The empirical material for this special issue included the overall curricula for all Nordic legal education, including overviews of all basic and elective courses, and the specific curricula for legal theory and international law. This material provides a snapshot of Nordic legal education in 2018 and a bird's eye view of how Nordic countries approach international law. The material does not provide me with any detailed information about whether there is a Nordic approach to the teaching of international law or about how international law courses are taught in practice, or what perspectives, approaches and examples different professors bring into their courses. It also does not give me insights into how international law is reflected on in other legal education courses. However, the material collected allows me to say something about where international law courses are placed within legal education, what the aim of the basic and elective courses are and what material is used. It gives me a bird's eye view of the types of subjects in international law included in legal education in the Nordic counties.

A quick glance reveals that there are many similarities in legal education in different places. Students are introduced to core legal subjects; there is a balance between training students to become legal practitioners and teaching law as an academic subject, as well as between providing students with opportunities to further explore their areas of interest through courses they can choose from, with typically an extensive essay to complete towards the end of their studies. All Nordic legal education also includes specific courses in international law. A quick review of the law programs and the course descriptions for international law courses show the courses are surprisingly similar: courses are usually placed after the second year of 
study; the courses extend over ten to 15 study weeks (although international law is sometimes included as one element of a course that extends over a whole semester and sometimes the international law content is divided among two courses); and the standard content is dominated by public international law, but it also tends to include international economics law, international human rights law and related subjects with a hint of international private law. Most international law courses also include a focus on European Union (EU) law.

The aim of the obligatory international law courses seems to largely be to provide students with a basic understanding of international law and its institutions. Many of the course descriptions use variations of formulations of aims, such as to provide "...basic understanding of international law with a particular focus on regulation for multilateral and regional economic and political cooperation" (International Law, Gothenburg University) and to enable students to solve and analyse questions relating to public international law, and that they are able to understand and critically assess public international law's processes and material law and public international law as a system (Kursbeskrivning Folkrätt, Stockholm University). The overview also shows that international law remains a largely 'theoretical' subject within legal education, in the sense that students are introduced to the history, institutions and treaties with broad strokes; they learn to observe the international legal systems but are not necessarily introduced to what it means to be an actor in that system. That is, the course is focused on learning about the international legal system but less about what it means to work with this system.

There are some exceptions. Some courses are evidently designed to make the students' understand how location matters for how we understand law and, in particular, for what aspects of the legal arena become important for us. Örebro University in Sweden has developed a 30-credit course entitled "Europe and the World". The course takes its starting point in how Swedish national law and its institutional structure situate themselves in the broader context of European and international law. Unsurprisingly, maybe, the legal education at Tromsö university, the most northern of the Nordic departments and faculties of law, include arctic governance and indigenous peoples' rights in their international law courses. At Odense University in Denmark, the focus is not on public international law, but on international 
private and trade law. The five-credit course takes its starting point in international sales transactions and their legal implications and seeks to provide students with the legal skills necessary to deal with a multitude of international or cross-border sales and transport-related issues.

A quick survey of the obligatory reading lists for the 2018 compulsory international law courses shows that in all seven law faculties or departments that provide legal education in Sweden, books by Swedish international legal scholars written mostly in Swedish (and sometimes in English) dominate, although basic works by British or other Englishspeaking scholars are also included. Course books that are used by several law faculties or departments that provide legal education include Sverige och Folkrätten by Said Mahmoudi, Ove Bring and Pål Wrange (2014) and An Introduction to the European Convention on Human Rights by Ian Cameron (2018). In the EU law components of international law courses, as EU law remains a topic often included in international law courses, although much EU law is also sprinkled throughout legal education, some books by Dutch and German authors can be found written in English, notably European Union Law by Robert Schutze (2018). The three legal institutions in Finland follow the same tendency: the bulk of the textbooks are written by Finnish authors (or authors residing in Finland) in Finnish or in English, or they are standard English language international law textbooks. Course books that are used in several courses include International Law by Jan Klabbers (2017), Uusi kansainvälinen oilkeus by Kari Hakapää (2010) and Textbook on International Law by Martin Dixon (2013). The three legal institutions in Denmark and Norway mainly include Danish, Norwegian and English language authors respectively, but the Norwegian core textbooks seem slightly broader as they include 'Norwegian topics' relevant for international law such as indigenous peoples' rights. However, the core books in all the Nordic institutions remain focused on the basic principles and only to a limited extent do they situate international law in context.

While the obligatory international law courses are fairly similar across the Nordic countries, the elective courses that are usually provided for students after the third year of legal studies show greater variety. The difference is most likely due to the elective courses being informed by the research done at the faculty. They are also often easier to change, thus creating more space for dealing with contemporary issues. There is some variation between the 
legal institutions in the Nordic countries, but all provide students with the opportunity to do advanced studies towards the end of their Masters' degrees. The advanced studies include both elective courses and a dissertation. While there are considerable differences between Nordic countries and specific law schools with regards to the number and the content of the elective courses, international law and related subjects are generally well represented among the elective courses. It is obvious that international law and global challenges - be they related to conflict, climate change, intellectual property or trade - are issues addressed in nonobligatory courses and in the later stages of legal education. Nordic countries do then, at the advanced level, provide law students with the opportunity to engage more deeply with complex international law subjects, however the focus remains theoretical and seldom seeks to situate students as future practitioners of international law in an increasingly complex and conflict-prone global context. The overview does not provide me with insights into what pedagogic approaches are used and to what extent these reflect the three lessons that I have deemed important or other lessons that seek to reflect international law as a living area of law where practical engagements can make a difference. There is of course much discussion and debate in international law classrooms and seminars that are not reflected in course curricula. In the next section, I will provide an example of one such pedagogic approach.

\section{Conflict, Afghanistan and International Law}

\section{Afghanistan and International Law}

The three lessons on international law outlined in the introduction and discussed from the point of view of scholarship on how international law is taught, I learnt while working in and on issues relating to Afghanistan. The post-World War II international legal system looks different when viewed through an "Afghanistan lens" than when viewed from Sweden or the Nordic countries. Afghanistan was one of the founding members of the United Nations and, like Sweden, it contributed to the early development of the post-World War II international legal and political project (Mani 2002; Schoiswohl 2006; Kouvo 2009). However, the two countries have had very different trajectories over the past seventy years: Sweden and Europe have 
been exceptionally prosperous and peaceful, while Afghanistan has spent more than half of the post-World War II era grappling with conflict. ${ }^{14}$ When teaching international law, I make extensive use of the 'Afghanistan lens' in order to shed light on how 'international' is situated and political, and how government approaches to it are eclectic. Before providing a practical example of this, below a brief account of the conflict in Afghanistan.

The conflict in Afghanistan has developed in parallel and intersected with key international developments. The modern conflict in Afghanistan started with a communist coup in 1978, followed by an invasion by the Soviet Union in 1979 (for a comprehensive analysis of the conflict, see Rubin 2002 and Rachid 2008). ${ }^{15}$ All through the 1980s, Afghanistan was one of the many battlefields of the Cold War, with the Red Army being challenged by Afghan resistance fighters trained and equipped by the CIA. Shortly after the end of the Soviet occupation, the Soviet Union collapsed. The US and the international community lost interest in Afghanistan and left the newly established Afghan government without support. The government soon fell apart and a new phase of the conflict, a bloody civil war, started.

Throughout the 1980s, millions of Afghans had fled to neighboring Pakistan and Iran. ${ }^{16}$ It is in the refugee camps across the border in Pakistan that the Taliban movement developed (Rashid 2001). In the midst of the anarchy of the civil war, the Taliban movement emerged and swiftly grabbed power. In the latter half of the 1990s, the largely unrecognized Taliban regime did not only force an exceptionally harsh form of Sharia law and Pashtun cultural codes onto the whole of the Afghan population, they also hosted other radical Islamic movements, including Al Qaida. After the 9/11 attacks, the US and the world's attention turned to Afghanistan.

\footnotetext{
${ }^{14}$ The narrative that the establishment of the UN, adoption of the UN Charter and international human rights treaties have contributed to an unprecedented era of peace, prosperity and protection of individual rights has also been challenged, not least by postcolonial and third world approaches to international law (Chimni 2017; Kapur 2018; Orford (ed.) 2006; Orford 2004; Pahuja 2013).

${ }^{15}$ For updated insights into the conflict, see the publications by the Afghanistan Analysts Network, www.aanafghanistan.org (accessed 2020-09-26) and the publications of the Afghanistan Research and Evaluation Unit https://areu.org.af/ (accessed 2020-09-26).

${ }^{16}$ With an estimated 2.7 million refugees worldwide, Afghans currently constitute the world's third largest refugee population after Syria and Venezuela, https://www.unhcr.org/refugee-statistics/ (accessed 2020-09-21). During the first phase of the conflict, after the Communist coup and during the Soviet occupation (1978-1989), roughly six million Afghans fled across the border to Iran and Pakistan,

https://afghanistan.iom.int/sites/default/files/Reports/afghanistan_migration_profile.pdf (accessed 2020-09-21). For an overview of the number of refugees and those internally displaced in Afghanistan throughout the conflict, see Schmeidl 2019.
} 
Although there were initial hopes that the US-led military operation that ousted the Taliban and the UN-supported state-building exercise in the early 2000s would bring peace to Afghanistan, this did not happen (Johnson and Leslie 2008; Maley 2006). Instead, security has gradually declined over the past 15 years and the conflict has escalated. ${ }^{17}$

The US decision legitimating the ousting of the unrecognized Taliban regime using the UN Charter's self-defense and NATO's collective defense clauses was broadly accepted, but also debated as it was not the Taliban that planned or conducted the attacks on US territory 11 September 2001 (Quigley 2003). The ways in which basic tenets of international human rights and humanitarian law were systematically altered to enable torture (so-called enhanced interrogation techniques) and excluding certain combatants (so-called unlawful combatants) from protection as prisoners of war was broadly rejected, but it was continued and it has had ripple effects well beyond the US and Afghanistan (Wilson 2005). However, besides the events that have drawn the attention of international lawyers and media, the war in Afghanistan provides an avalanche of examples of how the international community or the Afghan government have put in place policies and practices that seek to smooth over or by-pass breaches and violations of international law. Some of the lesser discussed - but for close observers of Afghanistan and for Afghans - well-known examples include direct foreign intervention in Afghan judicial proceedings in apostasy cases (Knust Rassekh Afshar 2006), the hiding and destruction of evidence of war crimes, including the killing of civilians by both Afghan and international parties to the Afghan conflict, ${ }^{18}$ efforts to by-pass the principle of nonrefoulement by international forces in Afghanistan (Droege 2009; Sassòli and Tougas 2011), the tacit acceptance that amnesty will be a necessary element of a peace deal in Afghanistan (Gossman and Kouvo 2013), and the condoning of Afghan security forces' gender-based and sexual violence against girls and women, but also against boys and men (Goldstein 2015; Glinski 2020; Conflict-Related Sexual Violence 2020). The conflict has also

\footnotetext{
${ }^{17}$ For insights into the declining security and increasing conflict in Afghanistan, see the past decade's UN civilian casualties reporting from Afghanistan, https://unama.unmissions.org/protection-of-civilians-reports (accessed 2020-09-26).

${ }^{18}$ The Physicians for Human Rights reporting of the destruction of evidence after a massacre where more than 2000 Taliban prisoners had been suffocated or shot by US and allied forces, see

https://phr.org/issues/investigating-deaths-and-mass-atrocities/assessments-and-documentation-of-masscrimes/assessments-in-afghanistan/assessments-in-afghanistan-dasht-e-leili-photos/ (accessed 2020-09-26).
} 
enabled Afghanistan to become the world's number one producer of opium, a trade that contributes to financing the conflict ${ }^{19}$, while also making a cadre of Afghans and their regional and international backers very rich (Chaynes 2007; Rashid 2008; Rubin 2002). Without too much exaggeration it could be argued that sidelining international law and ignoring or condoning violations of international law is part of the norm rather than the exception in Afghanistan (Gossman and Kouvo 2013; Kouvo and Mazoori 2011).

While most Afghans are tired of the conflict, it is now difficult to break out of the cycle of conflict. ${ }^{20}$ It is, as the former EU Special Representative for Afghanistan and long-time UN peace mediator, Francesc Vendrell, once told me that it is "easy to start a war, but almost impossible to end one". ${ }^{21} \mathrm{~A}$ variation of this statement was used by a senior Afghan diplomat at a student conference that I attended. The diplomat was asked if he had any advice to the Syrian nation that was then just facing its first years of a bloody civil war. The ambassador's advice was: Don't start the war.

At the time of writing, intra-Afghan peace talks have started in Doha, Qatar (Roehrs, Adili and Sadat 2020). The talks are one of the results of the agreement between the US and the Taliban, focused, inter alia, on the withdrawal of US forces from Afghanistan. The talks are significant, but they have not yet stalled the violence and they are a long way from ending more than four decades of conflict in Afghanistan. ${ }^{22}$ Peace remains elusive, and even if an intra-Afghan peace agreement could be ensured, the agreement would not overcome some of the aforementioned consequences of the conflict anytime soon. When this article was prepared for publication, the conflict in Afghanistan had taken yet another radical shift. In August 2021,

\footnotetext{
${ }^{19}$ Afghanistan is lead producer of opium (for figures of opium production throughout the conflict, see UNODC's crop monitoring survey here https://www.unodc.org/documents/cropmonitoring/Afghanistan/Afghanistan opium survey 2016 cultivation production.pdf, accessed 2020-09-21). The UNODC report also found that in 2016 one in three Afghan villages were involved in opium cultivation and that farm-gate value amounted to 898 million USD or $5 \%$ of Afghanistan's GDP. In the same year, the Taliban insurgency earned approximately 160 million USD from taxing opium cultivation, production, and trafficking. For further discussion on the Afghan 'war economy', see, for example, Goodhand 2004.

${ }^{20}$ For up to date overviews of the conflict and the peace process in Afghanistan, see dispatches and reports on the Afghanistan Analysts Network website, www.aan-afghanistan.org (accessed 2019-05-24).

${ }^{21}$ Discussion with author, Kabul 2006.

${ }^{22}$ One measure for the level of violent conflict is to what extent the conflict affects civilian populations. Since 2009, the UN has monitored civilian casualties in Afghanistan. In the first six months of 2020, the UN documented 3,458 civilian casualties (1,282 killed and 2,176 injured). Since 2009, the UN has documented almost 50,000 civilian casualties in Afghanistan. For UN reporting, see https://unama.unmissions.org/protection-ofcivilians-reports (accessed 2020-09-21).
} 
the Afghan President fled the country and the Taliban took over power. It is, as of yet, uncertain how restrictive and brutal the Taliban government will be, how the conflict will continue and the extent of the humanitarian crisis that Afghanistan will face.

In the next section, I will provide an example of how I have sought to integrate the 'reality' of the Afghan conflict and possible peace negotiations in international law teaching.

\section{Unpacking a Role-Play about Solving the Conflict in Afghanistan}

Over the past decade, students at the different universities where I have taught have been encouraged to engage with the conflict in Afghanistan and to use an "Afghanistan", and more broadly, a "conflict" lens on the postWorld War II international legal order. The focus on Afghanistan has helped me explain the geopolitics and international law, but also to dig into the different ways in which governments and international organizations have dealt with the conflict in Afghanistan. This has been done through lectures, but also through role-play focusing on the peace process in Afghanistan.

The peacemaking role-play was first developed for a course in law and development and transitional justice at the Brussels School of International Study (Kent University). The aim of the role-play was to provide students with an understanding of international law as situated and political through allowing them to place themselves in the positions of different parties to the Afghan conflict, all with very different perspectives and solutions for the conflict. The role-play also allowed students to become actors of conflict resolution. How they had prepared for the role-play, as well as their negotiation and networking skills were crucial to the outcome of the roleplay.

Over the years, the form and content of the role-plays have changed to adapt to developments in Afghanistan and demands of specific courses. ${ }^{23}$ However, most of the role-plays have been situated in the early confidencebuilding stage of a possible peace process. That is, they have been situated in the phase of the possible peace process that the parties to the Afghan conflict are entering into now. A phase where the parties to the conflict,

\footnotetext{
${ }^{23}$ The role-play was developed for a course on transitional justice that I have taught at the Brussels School of International Study (Kent University). An adapted version of the role-play has been used at the Transitional Justice Summer School of the Transitional Justice Institute (University of Ulster) and a course on human rights and conflict taught at the Birkbeck Law School. All in all, I have done about ten versions of the role-play.
} 
alone or through a mediator, seek to build trust in each other and the process through efforts to, for example, de-escalate the conflict, negotiate prisoner exchanges and slowly build a roadmap for negotiations (Mason and Matthias 2013).

The actual role-plays have included a few days of preparation, the roleplay (usually lasting a few hours) and a debriefing. In order to prepare, the students are provided background briefs about the Afghan conflict and the party to the conflict that they represent. The groups represented in the roleplay always include the Afghan and US governments, the Taliban and the United Nations, and sometimes the Pakistani government, the International Criminal Court, the European Union and networks of Afghan women's rights or human rights and war victims' organizations. The guidelines for the role-play have been simple, students have been told that it is important that the confidence-building ideally continues in a subsequent meeting with a specific agenda being scheduled, and that they should keep in mind the positions and the red lines of those that they represent. A few times, I have added a 'reality check' component to the preparation phase: students have had the opportunity to engage in online discussions with international and Afghan practitioners that provide a reality check for their analysis before they go into the role-play.

The actual role-plays have always been entertaining, not least as students get into their roles dressed up in their best 'suits-for-job-interviews', try to grow beards and learn to tie a turban in a week, or walk into the negotiation setting with United Nations coffee mugs or 'Make America Great Again' caps. Or, when a 'Taliban delegation' made up entirely of women eagerly tried to convince the other delegations that they had changed, that they now do believe that girls should go to school and that women should be able to work.

In the debriefings following the role-plays, students are provided opportunities to share what they learnt and if there was anything in particular that surprised or frustrated them. While I have not taken formal notes from the role-plays and the debriefings, I have always, when updating the role-play, reflected back on the previous one. Hence, I feel confident in sharing some personal impressions from the role-plays and the debriefings.

First, when choosing what positions they want to represent, students tend to want to represent the United Nations, civil society or the United States. 
They are less quick to choose to represent the Afghan government or the Taliban. When I have integrated other groups in the role-play, the students tend to choose being part of the ICC or EU delegations, rather than representing the Pakistani government. As I have done the role-play in courses relevant to international law, mostly at European universities, it is not surprising that the students prefer to represent the organizations and actors that they are currently learning about. They may of course also feel that it is less work having to figure out the position of international organizations or 'Western' governments than to figure out what key positions the Afghan government or the Taliban might take. However, regardless of who the students choose to represent, the exercise evidently helps them to understand how aspects of international law relevant for peacemaking, including the use of force and ceasefires, accountability for war crimes and women's rights seems to change meaning and relevance depending on who you are.

Second, the students quickly seem to pick up on what the stereotypical representations of the different actors are and what they are likely to say or not to say. The UN delegations tend to have an air of cool, international civil servants. Depending on what the students' impressions are of the UN, the civil servants engage in behind-the-scenes mediation and work hard to uphold international standards or lazily repeat non-committal policy language. The students who choose to represent the US government tend to develop an almost parodic sense of self-worth, they know that they are a key actor and they make sure that they are the center of attention. The students who represent civil society tend to go into the case study with the expectation that their cause - be it accountability, human rights or women's rights - will be taken seriously and that they are on an equal footing with governments, but they come out of the process frustrated because 'nobody cares' and 'nobody listens to us'. The experience of representing the Taliban tends to be the most transformative one. The students who represent the Taliban tend to go into the case study with ideas about the Taliban as 'the enemy' known mostly for their extreme positions and violence, but through the case study they learn more about the many reasons why people may have joined the Taliban and what it means to fight an international military force on the territory you call home. 
Third, the Afghan role-play can actually be quite disconcerting for students of international law. From early on in legal education, law students are taught to view law as neutral and objective, legal systems as coherent and stable and the rule of law as being above politics. It is not necessarily easy to have these ideas challenged. It also seems to be quite disconcerting to realize how little actual protection international law provides in situations of conflict or ensuring that international laws are protected during peace processes. Recurrent questions from mostly European students during the debriefings after the role-plays have been variations of: "But surely, the United Nations can force the warring parties to agree?", "According to international law there can be no amnesty for war crimes, so there must be a mechanisms for bringing Afghan warlords to justice?” and "Equality is guaranteed in international treaties and the Afghan Constitution, this must mean that women's rights cannot be sacrificed in a peace process?" Students who have grown up in or whose families have migrated from fragile, failed or conflict countries, on the other hand, tend to more readily recognize that peace is a luxury and that functioning systems or the rule of law cannot be taken for granted.

The role-play does concretely show students that location and perspective matters, that international law is political, and that actual individual action can matter for how international law is used and international events unfold. These lessons challenge basic assumptions about international law and allow students to envisage themselves as actors of international law, outside the evident legal adviser or court setting.

\section{Discussion}

I started this article with reference to the UNSG's opening remarks at the UNGA 2014, saying that the 'world's fasten seat belt sign is illuminated'. The aim was not to be alarmist or to contribute to a 'sense of cataclysm' that in the post-9/11 era has contributed to pushing aside pacifist methods of conflict resolution for the benefit of military solutions. The aim of the quote, together with the focus on my three lessons from working in Afghanistan, was to emphasize a need for international law scholarship and especially teaching that practically and constructively engages with our current world in crisis and the manifold societal challenges we are facing. Bluntly put, this involves shifting from a 'peace' to a 'conflict' lens when teaching international law. For me, a conflict lens does not entail viewing crisis, 
violence and abuse of people or the earth as inevitable, there are ample examples that it is not. Rather, I see a conflict lens as being the embodiment of the three lessons on which I have concentrated this article: international law is situated, it is political and that individual action matters. The first two lessons are by now well-documented in critical and in particular third world and postcolonial approaches to international law. From the perspective of (international) law, the third lesson is at first glance problematic, as it might give the impression that I am suggesting that the idea of rule of law and democratic governance can be or should be circumvented by individual action. This interpretation opens up a whole range of possible discussions on civil servant resistance and whistleblowing, which I have not discussed in this article. My approach is more practical and pragmatic: I am stating that as implementers of international law and contributors to international governance, individual engagement, knowledge and, importantly, compassion and curiosity matter. I am also convinced that it is important how we teach international law, and in this article I have sought to provide some examples of this.

The three lessons were approached from two different angles in this article. The first part focused on international law teaching in general and in particular focused on Nordic countries. The section showed the link between geopolitics and scholarship on international law and its teaching. It also showed how a comparative perspective on international law could contribute to a better understanding of one's own and others' biases and blind spots, and how they influence scholarship and teaching. Being aware of how, not the fundaments of international law, but dominant narratives about it are colored by location and politics, will make future international law professionals better problem-solvers for a world in crisis. The section also sought to analyze which perspectives are used when international law is taught in Nordic countries. The bird's eye view analysis suggests that the compulsory courses draw mainly on Anglo-American and Nordic scholarship on international law. While efforts are made to integrate perspectives relevant to the specific country (Denmark, Finland, Iceland, Norway and Sweden), there is little in the material that suggests that Western/European or Nordic perspectives are contextualized or critically analyzed. It is in the elective courses towards the end of a legal education that students are able to deepen their understanding of international law 
from different perspectives. This includes opportunities to delve into international law from contemporary, critical and practical perspectives. Students are able to choose courses on topics such as international environmental law, humanitarian law and emerging issues around digitalization and artificial intelligence; they are also able to gain practical experience through moot court exercises.

The second part focused on the conflict in Afghanistan and the extent to which international law, and especially international human rights and humanitarian law, has been marginalized and actively breached in Afghanistan. I also analyzed lessons from the peacemaking role-play that I have used to encourage students to engage with different perspectives and reflect on how these different perspectives alter approaches to international law. The Afghanistan peacemaking case study has been this author's concrete way of trying to promote students' understanding of an engagement with international law as situated, political and often dependent on the efforts of individual actors inside or outside institutions. While the case study falls short of being a systematic way of counterhegemonic international law teaching, it does, at least momentarily, reveal to law students how position, location and politics affect our understanding of international law.

Summing up the findings from the two parts, it can be argued that although much of the core of international law is focused on dealing with the use of force and armed conflict, law remains marginal in the politics of and day-to-day reality of conflict. This may be particularly prevalent when attempting to communicate international law's situatedness and politics, as well as the incoherence of the approaches of international organizations and government policies, as well as actions in conflict situations for (Nordic) law student audiences. Most Nordic law students can go through law school having only been introduced to the basics of the post-World War II international legal order taught from a European or Western perspective, with an emphasis on the distinction between international politics and law. This easily translates into assumptions about international law as a safeguard against conflict and predatory politics. Such assumptions obscure the prevalence of crisis, conflict and war as a constant presence within our global order. As a consequence, the realities of the millions of people who live with the risk of or ongoing armed conflict, or for whom 'governments' 
or the 'international community' represent just another layer of exploitative or oppressive structures, become equally obscured.

Some of the current global problems and international developments have come to challenge both the reality and perception of peace and the rule of law as the norm. The ongoing changes will provide opportunities for subtly or boldly reshaping and redefining values and norms at national and international levels. While we may not yet know who will put an end to these opportunities, whose ideas will come to dominate and what the result will be, the ongoing debates about migration, national and international security, climate change etc. do suggest that such debates will be fierce and that they will be fought in different arenas, including that of international law. It is important that current students and the future scholars and practitioners of international law are equipped to navigate these changes, contributing to them constructively and with integrity.

What will this imply for how we teach international law? First, it is useful to shift away from the assumption that peace (and prosperity) is the norm and that conflicts happen elsewhere. I believe that we have much to learn from how international law works (or not) in conflict and fragile states. These tend to include states where international interests - be they from other governments, multinational companies or organized criminal networks - affect politics, governance/rule of law and the everyday lives of people. Second, it is essential that we not only ask 'Is international law, law?', but that we also explain that one of the consequences of the politics of international law, is that international law, the interests it defends, its values and norms and, to a lesser extent, its implementation, are incoherent. Making sure that international law students understand international law as political, also means making sure that students understand that working with international law implies making ethical choices. The early career position reviewing defense sector contracts at a multinational company, may actually result in people being killed. Although it might make sense to work as a human rights adviser for a military training mission, it is important to recognize that the position is also about legitimizing training (and equipping) militaries that may not have functioning command-and-control structures, and no functioning accountability structures in contexts where government security forces are already untrustworthy. 


\section{References}

Al Attar, Mohsen and Tava, Vernon. 2010. TWAIL Pedagogy - Legal Education for Emancipation. The Palestine Yearbook of International Law Vol. XV: 7-40.

Anghie, Anthony. 2012. Imperialism, Sovereignty and the Making of International Law. Cambridge: Cambridge University Press.

Aoláin, Fionnula. 2016. The Cloak and Dagger Game of Derogation. Reader, Cambridge: Cambridge University Press.

Baaz, Mikael. 2019. Law and Politics in the International Society. Stockholm: Jure.

Bailliet, Cecilia M. 2014. Untraditional Approaches to Law: Teaching the International Law of Peace. Santa Clara J. Int'l L 12: 1-28.

Bailliet, Cecilia M. 2016. A Nordic approach to promoting women's rights within international law: internal v. external perspectives NJIL 85(4): 268-294.

Beck, Robert J. 2010. Teaching International Law as a Partially Online Course: The Hybrid/Blended Approach to Pedagogy. International Studies Perspectives 11: 273-290.

Bjorgvinsson, David Thor. 2016. The Effect of the Judgments of the ECtHR before the National Courts - A Nordic Approach? NJIL 85(4): 303-321.

Cameron, Ian. 2018. An Introduction to the European Convention on Human Rights. Uppsala: Iustus.

Cattafi, Carmelo. 2018. Teaching Methods in International Law. Journal of International Education Research 14 (2): 9-16.

Cerone, John. 2011. Caveat Doctor: International Law and the Criminalization of Teaching It. Suffolk Transnational Law Review 34 (3): 487-506.

Charlesworth, Hilary. 2011. Talking to ourselves? Feminist scholarship in international law. In Sari Kouvo and Zoe Pearson (eds.). Feminist Perspectives on Contemporary International Law: Between Resistance and Compliance?. London: Hart Publishing, 17-32.

Chaynes, Sarah. 2007. The Punishment of Virtue. London: Portobello Books Ltd. 
Chimni, B. S. 2017. International Law and World Order. A Critique of Contemporary Approaches. Cambridge: Cambridge University Press, $2^{\text {nd }}$ edition.

Conflict-Related Sexual Violence. 2020. Report of the UN Secretary General. S/2020/487.

Dixon, Martin. 2013. Textbook on International Law. Oxford: Oxford University Press.

Droege, Cordula. 2008. Transfers of detainees: Legal framework, nonrefoulement and contemporary challenges. International Review of the Red Cross 90 (871): 669-701.

Dunoff, Jeffrey L. and Pollack, Mark A. (eds.). 2013. Interdisciplinary Perspectives on International Law and International Relations. Cambridge: Cambridge University Press.

Gamble, J. 2007. Teach or Get Off the Lectern: Impediments to Improving International Law Teaching. ILSA Journal of International \& Comparative Law 13 (2): 379-386.

Gazzini, Tarcisio. 2016. A Fresh Look at Teaching International Law - A Few Pedagogical Considerations in the Age of Communications. Leiden Journal of International Law 29 (4): 971-978.

Glinski, Stefanie. 2020. Husband, father, sex worker: As adults, Afghanistan's 'dancing boys' lead double lives. Reuters. 4 May. https://www.reuters.com/article/us-afghanistan-lgbt-rights-feature-trfnidUSKBN22G092 (Accessed 2020-09-26).

Gjørtz Howden, Julie. 2016. Community of Interest and the Nordic Management of International Water Courses. NJIL 85(4): 348-367.

Goodhand, Jonathan. 2004. From War Economy to Peace Economy? Reconstruction and State-Building in Afghanistan. Journal of International Affairs 58 (1): 155-174.

Goldstein, Joseph. 2015. U.S. Soldiers Told to Ignore Sexual Abuse of Boys by Afghan Allies. New York Times. 20 September.

https://www.nytimes.com/2015/09/21/world/asia/us-soldiers-told-toignore-afghan-allies-abuse-of-boys.html (Accessed 2020-09-26).

Gossman, Patricia and Kouvo, Sari. 2013. Tell us how this will End? Transitional Justice and Prospects for Peace in Afghanistan. Kabul: Afghanistan Analysts Network.

Hakapää, Kari. 2010. Uusi kansainvälinen oikeus. Helsinki: Talentum. 
Hilson, Mary. 2008. The Nordic Model. Scandinavia Since 1945. London:

Reaktion Books.

International Law Teaching. 1925. The American Journal of International Law

19 (2): 362. http://www.jstor.org/stable/2189266 (Accessed September 2020-09-22).

International law/HRO600 Internationell rätt, 15 högskolepoäng. 2018.

Department of Law, School of Business, Economics and Law,

Gothenburg University, Sweden.

Israel, Mark, Skead, Natalie, Heath, Mary, Hewitt, Anne, Galloway, Kate and Steel, Alex. 2017. Fostering Quiet Inclusion: Interaction and Diversity in the Australian Law Classroom. Journal of Legal Education 66 (2): 332356.

Johnson, Chris and Leslie, Jolyon. 2008. Afghanistan. The Mirage of Peace.

London: Zed Books, $2^{\text {nd }}$ edition.

Kapur, Ratna. 2018. Gender, Alterity and Human Rights. Freedom in a

Fishbowl. Cheltenham: Elgar Studies in Legal Theory.

Kennedy, David. 1985. International Legal Education. Harvard International Law Journal 26 (2): 361-384.

Kennedy, David W. 2009. The Rights of Spring: A Memoir of Innocence Abroad. Princeton: Princeton Univ. Press.

Klabbers, Jan. 2017. International Law. Cambridge: Cambridge University Press.

Knust Rassekh Afshar, Mandana. 2006. The Case of an Afghan Apostate The Right to a Fair Trial Between Islamic Law and Human Rights in the Afghan Constitution. Max Planck Yearbook of United Nations Law 10: 591605.

Koskenniemi, Martti. 2009. The Gentle Civilizer of Nations. The Rise and Fall of International Law 1870-1960. Cambridge: Cambridge University Press. Kouvo, Sari. 2009. State-building and Rule of Law: Lessons from Afghanistan? Rome: NATO Defense College.

Kouvo, Sari and Mazoori, Dallas. 2011. Reconciliation, Justice and Mobilization of War Victims in Afghanistan. International Journal of Transitional Justice 5(3): 492-503.

Kursbeskrivning Folkrätt, 6 hp. PM 2018-04-04. Juridiska Fakulteten, Stockholms universitet. 
McNair, Arnold D. 1943. The Need for the Wider Teaching of International Law. Transactions of the Grotius Society 29: 85-98.

Mahmoudi, Said, Bring, Ove and Wrange, Pål. 2014. Sverige och Folkrätten. Stockholm: Norstedts juridik.

Maley, William. 2006. Rescuing Afghanistan. Sydney: UNSW Press.

Mani, V. S. 2002. The Fifth Afghan War and International Law. Economic and Political Weekly 37(4): 294-298.

Mason, Simon J. A. and Matthias Siegfried. 2013. Confidence Building Measures (CBMs) in Peace Processes. In Managing Peace Processes: Process related questions. A handbook for AU practitioners. Volume 1. African Union and the Centre for Humanitarian Dialogue, 57-77. https://www.hdcentre.org/wp-content/uploads/2016/07/AU-HandbookVolume-I-Process-related-questions-July-2013.pdf (Accessed 2021-05-19).

Noll, Gregor. 2016. Nostalgia: A Nordic International Law. NJIL 85(4): 265280.

Orford, Anne (ed.). 2006. International Law and its Others. Cambridge: Cambridge University Press.

Orford, Anne. 2004. Reading Humanitarian Intervention. Human Rights and the Use of Force in International Law. Cambridge: Cambridge University Press.

O’Flaherty, Michael (ed.). 2007. The Human Rights Field Operation: Law, Theory and Practice. US: Palgrawe. New ed edition.

Otto, Dianne. 2017. Beyond Legal Justice: Some Personal Reflections on People's Tribunals, Listening and Responsibility. London Review of International Law 5 (1): 225-249.

Otto, Dianne. 2000. Handmaidens, Hierarchies and Crossing the PublicPrivate Divide in the Teaching of International Law. Melbourne Journal of International Law (3): 35-69.

Pettersson, Olof. 2005. Nordisk politik. Stockholm: Norstedts Juridik AB.

Puhaju, Sundhya. 2013. Decolonising International Law. Development, Economic Growth and the Politics of Universality. Cambridge: Cambridge University Press.

Rashid, Ahmed. 2008. Descent into Chaos. The United States and the Failure of Nation Building in Pakistan, Afghanistan and Central Asia. New York: Viking. 
Rashid, Ahmed. 2001. Taliban. The Story of Afghan Warlords. London: Pan Books.

Roberts, Anthea. 2017. Is International Law International? Oxford: Oxford University Press.

Roehrs, Christine, Adili, Ali and Sadat, Sayed Asadullah. 2020. Two Parties Too Wary for Peace? Central questions for talks with the Taleban in Doha. Afghanistan Analysts Network, September 11. https://www.afghanistananalysts.org/en/reports/war-and-peace/two-parties-too-wary-for-peacecentral-questions-for-talks-with-the-taleban-in-doha/ (Accessed 2020-0926).

Rubin, Barnett R. 2002. The Fragmentation of Afghanistan. State Formation and Collapse in the International System. New Haven and London: Yale University Press.

Saberi, Hengameh. 2015. Virtue Pedagogy and International Law Teaching. Osgoode Legal Studies Research Paper Series. 123.

Sassòli, Marco and Tougas, Marie-Louise. 2011. International Law Issues Raised by the Transfer of Detainees by Canadian Forces in Afghanistan. McGill Law Journal / Revue de droit de McGill 56:4: 959-1010.

Schmeidl, Susanne. 2019. Four Decades of Afghan Displacement. BPD Längerprofile.

https://www.bpb.de/gesellschaft/migration/laenderprofile/284416/fourdecades-of-afghan-displacement (Accessed 2020-09-21).

Schoiswohl, Michael. 2006. Linking the International Legal Framework to Building the Formal Foundations of a "State at Risk": Constitutionmaking and International Law in Post-conflict Afghanistan. Vanderbilt Journal of Transnational Law 39(3): 819-845.

Schutze, Robert. 2018. European Union Law. Cambridge: Cambridge University Press.

Schwöbel-Patel, Christine. 2018. Teaching International Law. Oxford Bibliographies of International Law

https://www.oxfordbibliographies.com/view/document/obo9780199796953/obo-9780199796953-0166.xml (Accessed 2019-05-24).

UN Doc. GA/11560 https://www.un.org/press/en/2014/ga11560.doc.htm (accessed 2019-05-24).

Quigley, John. 2003. The Afghanistan War and Self-Defense. Val. U. L. Rev. 37: 541-561. 
Zahralddin-Aravena, Rafeal X. 2001. International Legal Education. International Lawyer (ABA) 35 (2): 793-810.

Zidra, Andraě and Gauci, Jean-Pierre (eds.). 2016. The Role of Legal Advisers in International Law. Leiden: Brill.

Whittuck, E. A. 1917. International Law Teaching. Problems of the War 3: 4360.

Wilson, Richard. 2005. Human Rights in the 'War on Terror'. Cambridge: Cambridge University Press.

Wind, Marlene. 2016. Do Scandinavian Care about international law? A Study of Scandinavian Judges' Citation Practice to International Law and Courts. Nordic Journal of International Law 85(4): 281-302.

\section{Notes on contributor}

Sari Kouvo is an associate professor in international law at the Department of Law at the University of Gothenburg. Kouvo's previous engagements include co-director of the Afghanistan Analysts Network, a field-based policy research organisation focused on politics and security in Afghanistan, policy officer at the European External Action Service, head of program at the International Centre for Transitional Justice, researcher at Amnesty International and special adviser to the EU Special Representative for Afghanistan. Kouvo has taught at Kent University, Vrije Universitet Brussels and Birkbeck University, and she has held visiting fellowships at the Australian National University, Abo Academy, NATO Defense College and Kent and Keele universities. She has acted as a consultant for the Swedish International Development Agency, the Swedish Afghanistan Committee, UN Women and the European Peace Liaison Office. She has published widely on international law and Afghanistan-related topics. 